\title{
What are the Possible Implications for Androgen Replacement Therapy on Central Nervous System Function in Aging Men?
}

\section{Rebecca L. Cunningham*}

Department of Pharmacology and Neuroscience, University of North Texas Health Science Centre at Fort Worth, Fort Worth, TX 76107, USA

\section{Aging and Steroid Hormones}

Hypogonadism is a clinical condition depicted by low androgen levels and associated with low muscle mass and strength, decreased ratio of lean body mass to adipose tissue, osteoporosis, decreased libido, decreased hematocrit, impaired cognition, and mood disorders [1]. It has been well established that aging is associated with decreased testosterone levels in males, and by 80 years of age, $40 \%$ of men have serum testosterone levels within the hypogonadal range [2]. Hypogonadism in aging males is often called andropause or androgen deficiency of the aging male (ADAM) [3]. However, assessment of andropause in aging males is difficult due to several factors, such as varying methods of testosterone measurements (total testosterone, bioactive testosterone not bound to sex hormone-binding globulin (SHBG), and free testosterone not bound to SHBG or albumin proteins) [4]. Further complicating diagnoses is that SHBG levels increase during aging, resulting in decreased bioactive and free testosterone levels [4]. Since andropause can affect the quality of life for aging men and the elderly population is predicted to double by 2025, investigation of andropause becomes imperative [5].

\section{Androgen Replacement Therapy}

In aging males, low testosterone levels are predictive of future development of mobility limitations and frailty [6,7]. Androgen replacement therapy (ART) in elderly male subjects has been considered as a restorative/protective treatment modality against various disorders associated with aging [8-11]. ART is currently only indicated by the FDA for males that have been diagnosed with hypogonadism. The Endocrine Society's clinical practical guideline for ART in adult men with testosterone deficiency has defined hypogonadism in males as "a clinical syndrome that results from failure of the testis to produce physiological levels of testosterone and a normal number of spermatozoa due to a disruption of one or more levels of the hypothalamic-pituitary-gonadal (HPG) axis" [12]. Primary hypogonadism is characterized by high luteinizing hormone and follicle stimulating hormone levels in response to diminished HPG feedback, while secondary hypogonadism is characterized by low testosterone levels associated with low or normal luteinizing hormone or follicle stimulating hormone levels [13].

Medications that have been approved by FDA to treat hypogonadism include several Schedule III controlled substances, such as testosterone injections, transdermal testosterone patches/ gels, and oral testosterone formulations [14]. In the United States, alone, prescription sales of testosterone products have increased more than 500 percent since 1993 [15]. However, the data obtained to date that describe the protective effects of ART in elderly men have been equivocal, in contrast to findings in younger hypogonadal men $[16,17]$. Further, concern about the efficacy of ART in aging men prompted the National Institute of Aging and the National Cancer Institute to request that the Institute of Medicine conduct a 12-month study to evaluate the current understanding of the potential benefits and adverse effects of ART. A major theme in the analysis and recommendation was that additional work must be done before clear decisions can be made about the future of ART [18].

\section{Androgen Replacement Therapy and the Central Nervous System}

Our understanding of steroid hormone biology during aging is incomplete and current data about hypogonadism in the aging male population has been equivocal on the effects of testosterone on various endpoints, in contrast to findings in younger hypogonadal men $[16,17]$. The current contraindications for ART in aged males consist of obstructive benign prostatic hyperplasia, obstructive pulmonary disease, heavy smokers, clinical prostatic carcinoma, polycythemia, mammary carcinoma, prolactinoma, and dyslipidemia [19] Interestingly, the effects of ART on the central nervous system have not been thoroughly examined, even though aging and male gender are two of the clinical risk factors for neurodegenerative disorders, such as Parkinson's disease [20,21]. A possible explanation for the inconsistent reports in aged men may be that ART has both positive and negative therapeutic effects, depending on the oxidative stress load. Oxidative stress has been shown to contribute to both aging [22$24]$ and neurodegeneration $[20,21,25,26]$. Studies have determined that oxidative stress may mediate the apoptotic loss of dopamine neurons in neurodegenerative diseases, such as Parkinson's disease [27-29]. Further complicating the issue of ART and aging, androgens can also induce oxidative stress in dopamine neurons [30]. The effects of androgens on neurodegeneration are controversial. Animal studies suggest that the lack of androgens contribute to oxidative stress and neurodegeneration [31-33], conversely other studies suggest that androgens can mediate oxidative stress and neurodegeneration [34-37]. Available data indicate that there is an existing gap in our understanding of the efficacy and contraindications of ART in the elderly male population with regard to aging associated oxidative stress burden and subsequent neurodegeneration. Therefore, it is extremely important for the scientific community to develop agreement about ART safety in aging males, while taking into consideration possible ART-induced effects on the central nervous system along with the current contraindications associated with ART.

\section{References}

1. Tenover JL (1999) Testosterone replacement therapy in older adult men. Int $J$ Androl 22: 300-306.

2. Kaufman JM, Vermeulen A (1997) Declining gonadal function in elderly men Baillieres Clin Endocrinol Metab 11: 289-309.

*Corresponding author: Rebecca L. Cunningham, Ph.D, Department of Pharmacology and Neuroscience, University of North Texas Health Science Centre at Fort Worth, 3500 Camp Bowie Blvd, Fort Worth, TX 76107, USA, Tel: 817-7355080; Fax: 817-735-0408; E-mail: Rebecca.Cunningham@unthsc.edu

Received March 17, 2012; Accepted March 20, 2012; Published March 22, 2012

Citation: Cunningham RL (2012) What are the Possible Implications for Androgen Replacement Therapy on Central Nervous System Function in Aging Men? Steroids Hormon Sci S2:e001. doi:10.4172/2157-7536.S2-e001

Copyright: (C) 2012 Cunningham RL. This is an open-access article distributed under the terms of the Creative Commons Attribution License, which permits unrestricted use, distribution, and reproduction in any medium, provided the original author and source are credited. 
Citation: Cunningham RL (2012) What are the Possible Implications for Androgen Replacement Therapy on Central Nervous System Function in Aging Men? J Steroids Hormon Sci S2:e001. doi:10.4172/2157-7536.S2-e001

3. Gray A, Feldman HA, McKinlay JB, Longcope C (1991) Age, disease, and changing sex hormone levels in middle-aged men: results of the Massachusetts Male Aging Study. J Clin Endocrinol Metab 73: 1016-1025.

4. Miner MM, Seftel AD (2007) Testosterone and ageing: what have we learned since the Institute of Medicine report and what lies ahead? Int J Clin Pract 61 622-632.

5. Mathers CD, Sadana R, Salomon JA, Murray CJ, Lopez AD (2001) Healthy life expectancy in 191 countries, 1999. Lancet 357: 1685-1691.

6. Krasnoff JB, Basaria S, Pencina MJ, Jasuja GK, Vasan RS, et al. (2010) Free testosterone levels are associated with mobility limitation and physical performance in community-dwelling men: the Framingham Offspring Study. J Clin Endocrinol Metab 95: 2790-2799.

7. Hyde Z, Flicker L, Almeida OP, Hankey GJ, McCaul KA et al. (2010) Low free testosterone predicts frailty in older men: the health in men study. J Clin Endocrinol Metab 95: 3165-3172.

8. Morales A, Johnston B, Heaton JP, Lundie M (1997) Testosterone supplementation for hypogonadal impotence: assessment of biochemical measures and therapeutic outcomes. J Urol 157: 849-854.

9. Tenover JS (1992) Effects of testosterone supplementation in the aging male. J Clin Endocrinol Metab 75: 1092-1098.

10. Pike CJ, Carroll JC, Rosario ER, Barron AM (2009) Protective actions of sex steroid hormones in Alzheimer's disease. Front Neuroendocrinol 30: 239-258.

11. Mitchell E, Thomas D, Burnet R (2006) Testosterone improves motor function in Parkinson's disease. J Clin Neurosci 13: 133-136.

12. Bhasin S, Cunningham GR, Hayes FJ, Matsumoto AM, Snyder PJ, et al (2010) Testosterone therapy in men with androgen deficiency syndromes: an Endocrine Society clinical practice guideline. J Clin Endocrinol Metab 95: 25362559.

13. Matsumoto AM (2002) Andropause: clinical implications of the decline in serum testosterone levels with aging in men. J Gerontol A Biol Sci Med Sci 57: M76-M99.

14. Petak SM, Nankin HR, Spark RF, Swerdloff RS, Rodriguez-Rigau LJ, et al. (2002) American Association of Clinical Endocrinologists Medical Guidelines for clinical practice for the evaluation and treatment of hypogonadism in adult male patients--2002 update. Endocr Pract 8: 440-456.

15. Bhasin S, Buckwalter JG (2001) Testosterone supplementation in older men: a rational idea whose time has not yet come. J Androl 22: 718-731.

16. Okun MS, Fernandez HH, Rodriguez RL, Romrell J, Suelter M, et al. (2006) Testosterone therapy in men with Parkinson disease: results of the TEST-PD Study. Arch Neurol 63: 729-735.

17. Cunningham GR, Toma SM (2010) Why Is Androgen Replacement in Males Controversial? J Clin Endocrinol Metab 96: 38-52.

18. Testosterone and aging: Clinical research directions. Committee on assessing the need for clinica trials of testosterone replacement therapy. (National Academies Press, Washington D.C., 2003).

19. Vermeulen A (2001) Androgen replacement therapy in the aging male--a critical evaluation. J Clin Endocrinol Metab 86: 2380-2390.
20. Schrag A, Ben-Shlomo Y, Quinn NP (2000) Cross sectional prevalence survey of idiopathic Parkinson's disease and Parkinsonism in London. BMJ 321: 21 22.

21. Gillies GE, Murray HE, Dexter D, McArthur S (2004) Sex dimorphisms in the neuroprotective effects of estrogen in an animal model of Parkinson's disease. Pharmacol Biochem Behav 78: 513-522.

22. Harman D (1981) The aging process. Proc Natl Acad Sci U S A 78: 7124-7128.

23. Doyle KP, Simon RP, Stenzel-Poore MP (2008) Mechanisms of ischemic brain damage. Neuropharmacology 55: 310-318.

24. Mehta SL, Manhas N, Raghubir R (2007) Molecular targets in cerebral ischemia for developing novel therapeutics. Brain Res Rev 54: 34-66.

25. Thanvi B, Lo N, Robinson T (2005) Vascular parkinsonism--an important cause of parkinsonism in older people. Age Ageing 34: 114-119.

26. Farooqui T, Farooqui AA (2009) Aging: an important factor for the pathogenesis of neurodegenerative diseases. Mech Ageing Dev 130: 203-215.

27. Hanrott K, Gudmunsen L, O’Neill MJ, Wonnacott S (2006) 6-hydroxydopamineinduced apoptosis is mediated via extracellular auto-oxidation and caspase 3-dependent activation of protein kinase Cdelta. J Biol Chem 281: 5373-5382.

28. Lotharius J, Brundin P (2002) Pathogenesis of Parkinson's disease: dopamine vesicles and alpha-synuclein. Nat Rev Neurosci 3: 932-942.

29. Hirsch EC, Faucheux B, Damier P, Mouatt-Prigent A, Agid Y (1997) Neuronal vulnerability in Parkinson's disease. J Neural Transm Suppl 50: 79-88.

30. Cunningham RL, Giuffrida A, Roberts JL (2009) Androgens Induce Dopaminergic Neurotoxicity via Caspase-3-Dependent Activation of Protein Kinase Cdelta. Endocrinology 150: 5539-5548.

31. Pan Y, Zhang H, Acharya AB, Patrick PH, Oliver D, et al. (2005) Effect of testosterone on functional recovery in a castrate male rat stroke model. Brain Res 1043: 195-204.

32. Cheng J, Hu W, Toung TJ, Zhang Z, Parker SM, et al. (2009) Age-dependen effects of testosterone in experimental stroke. J Cereb Blood Flow Metab 29 486-494.

33. Ramsden M, Shin TM, Pike CJ (2003) Androgens modulate neuronal vulnerability to kainate lesion. Neuroscience 122: 573-578.

34. Dluzen D, Jain R, Liu B (1994) Modulatory effects of testosterone on 1-methyl4-phenyl-1,2,3,6-tetrahydropyridine-induced neurotoxicity. J Neurochem 62 94-101.

35. Murray HE, Pillai AV, McArthur SR, Razvi N, Datla KP, et al. (2003) Dose- and sex-dependent effects of the neurotoxin 6-hydroxydopamine on the nigrostriatal dopaminergic pathway of adult rats: differential actions of estrogen in males and females. Neuroscience 116: 213-222.

36. Yang SH, Perez E, Cutright J, Liu R, He Z, et al. (2002) Testosterone increase neurotoxicity of glutamate in vitro and ischemia-reperfusion injury in an anima model. J Appl Physiol 92: 195-201.

37. Cunningham RL, Macheda T, Watts LT, Poteet E, Singh M, et al. (2011) Androgens exacerbate motor asymmetry in male rats with unilateral 6-hydroxydopamine lesion. Horm Behav 60: 617-624. 